\title{
Simple Extraction and Rapid HPLC Method for Tocopherol Analysis in Marine and
}

\section{Fresh-water Fish Species}

\author{
Fatih ÖzoGuL ${ }^{*}$, Yesim Özogul and Esmeray KuLEY \\ Department of Seafood Processing Technology, Faculty of Fisheries, Cukurova University, 01330, Adana, Turkey
}

Received May 9, 2011; Accepted August 31, 2011

A rapid high-performance liquid chromatographic (HPLC) method with simple extraction procedure for the determination of tocopherols in seafood was developed. A continuous isocratic elution system was used for the analysis with a mixture of acetonitrile and methanol. Tocopherols were identified by comparison of retention times and peak area values with standard of $\alpha$-, $\beta$-, $\gamma$ - and $\delta$-tocopherols. The HPLC technique used showed good performance parameters (linearity $\mathbf{r}^{2}=0.9999$, and relative standard devia-

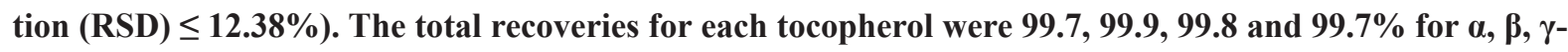
and $\delta$, respectively. This method was then applied to freshwater and seawater fish species to detect their tocopherol contents. Significant differences $(P<0.05)$ were observed in the content of tocopherol among fish species. The highest content was obtained from shrimp $(81.3 \mathrm{mg} / \mathrm{kg})$, while the lowest was found for whiting $(9.8 \mathrm{mg} / \mathrm{kg})$.

Keywords: fresh water fish, marine fish, tocopherol, HPLC method, extraction procedure

\section{Introduction}

Tocopherols are known to be secondary antioxidants which react with peroxide radicals, and inactivate them (Porter et al., 1995; Nogala-Kalucka, 2003). Tocopherol in nature is found as eight forms, including $\alpha-, \beta-, \gamma$ - and $\delta$-tocopherols, and four tocotrienols (Slover, 1970). In humans, $\alpha$-tocopherol is the most important and active form within the vitamin $\mathrm{E}$ group. The most favourable concentration of $\alpha$-tocopherol in human plasma is recommended to be greater than $10 \mathrm{mg} / \mathrm{L}$ (Garrow et al., 2000).

Many studies have reported that suboptimal levels of $\alpha$-tocopherol in plasma are associated with several health problems such as coronary heart disease, atherogenesis, stroke, cancer and other degenerative and neurological diseases (Weisburger, 1997; Li et al., 1999; Sinclair et al., 2000; Schoene, 2001; Ribarova et al., 2003; Nirungsan and Thongnopnua 2006). In addition, vitamin E supplements have shown prospective beneficial properties against coronary heart disease, diabetes and cystic fibrosis (Nirungsan and Thongnopnua, 2006).

It is important to achieve a successful determination of

*To whom correspondence should be addressed.

E-mail: fozogul@cu.edu.tr the vitamin E constituents which are quantitatively extracted from the food in a form that can be accurately measured by the HPLC technique. The HPLC method was first applied to the resolution of vitamin $\mathrm{E}$ and other fat-soluble vitamins by Schmit et al. (1971) and later by Williams et al. (1972). There are also reference methods for the analysis of tocopherol, such as those suggested by AOAC International (AOAC, 2000), CEN (CEN, 2000) and LMBG (LMBG, 1996). Extraction of tocopherols and tocotrienols before quantification by HPLC, depending on the sample, is usually performed by direct solvent extraction or saponification (alkali hydrolysis) (Eitenmiller and Lee, 2004).

Although several HPLC methods for tocopherol analysis have been reported, they have been applied to aquatic organisms and fish feed (Huo et al., 1999), European catfish muscle (Ng et al., 2004), microalgae (Huo et al., 1997), and liver and heart tissues of piglets (Kramer et al., 1997). It is thus necessary to develop a method that is convenient, a simple, less time-consuming, accurate and practical enough for tocopherol analysis for seafood. Therefore, the purpose of this study was to provide simple extraction and rapid HPLC method for tocopherols in seafood. 


\section{Materials and Methods}

Sample extraction Eleven fish (seawater and freshwater) species were used for tocopherol analysis, which were whiting (Merlangius merlangus), red mullet (Mullus barbatus barbatus), Atlantic salmon (Salmo salar), Atlantic horse mackerel (Trachurus trachurus), common sole (Solea solea), common seabream (Pagrus pagrus), gilthead seabream (Sparus aurata), European anchovy (Engraulis encrasicolus), European perch (Perca fluviatilis), European eel (Anguilla anguilla), and shrimp (Parapenaus longirostris). Triplicate samples of each fish species were taken for tocopherol analysis. Fish obtained freshly from a local market were immediately gutted and washed. For tocopherol determination, $1 \mathrm{~g}$ dorsal part of fish muscle without skin was chopped, weighed and transferred to Falcon tube (Isolab, Werheim, Germany) wrapped with aluminium foil. After that, $3 \mathrm{~mL}$ acetonitrile, $1 \mathrm{~mL}$ 2-propanol, and $1 \mathrm{~mL} 0.1 \%$ methanolic butylated hydroxytoluene were added into the each tube. The mixture was homogenized with a Ultra-Turrax homogenizer (T 25 basic IKA-WERKE, Staufen, Germany) for 2 min at $0^{\circ} \mathrm{C}$. The aliquot was then transferred to a centrifuge tube wrapped with aluminium foil and centrifuged at 18000 rpm for $10 \mathrm{~min}$ at $4^{\circ} \mathrm{C}$. The upper phase $(1 \mathrm{~mL})$ was taken and filtered using $0.45 \mu \mathrm{m}$ filter. After that, $2 \mu \mathrm{L}$ aliquot was injected into the HPLC with a microsyringe (Hamilton, Co., Renco, NV, USA) for the tocopherol analysis.

Apparatus High-performance liquid chromatography (HPLC) analyses were made using a Shimadzu Prominence HPLC apparatus (Shimadzu, Kyoto, Japan) equipped with a RF-10AXL fluorescence detector and two binary gradient pumps (Shimadzu LC-10AT), autosampler (SIL 20AC), column oven (CTO-20AC), and a communication bus module (CBM-20A) with valve unit FCV-11AL was used. The column, purchased from Phenomenex (Macclesfield, Cheshire, UK), was packed with reversed-phase Develosil $5 \mu$ RPAQUEOUS $(150 \times 4.6 \mathrm{~mm})$. Tocopherols were purchased from Sigma-Aldrich (Munich, Germany) and the mobile phase consisted of acetonitrile and methanol. Chromatographic separation was carried out using continuous isocratic elution with the HPLC grade acetonitrile (eluant A) and methanol (eluant B). HPLC isocratic profile was $50 \%$ acetonitrile and $50 \%$ methanol and the flow rate was $1.0 \mathrm{~mL} /$ min throughout the whole separation. The total separation time was $12 \mathrm{~min}$ and the isocratic elution was run for $15 \mathrm{~min}$ to ensure full separation. The injection volume was $2 \mu \mathrm{L}$ and detection was monitored with a fluorescence detector at 295 and $330 \mathrm{~nm}$ wavelengths for excitation and emission, respectively. A standard curve for each tocopherol in the range of $0.01-10 \mathrm{mg} / \mathrm{mL}$ was prepared. Correlation coefficients $\left(\mathrm{r}^{2}\right)$ and relative standard deviations (RSD) of peak areas against tocopherol standard concentrations for each compound were calculated after injecting 8 replicates of each tocopherol standard solution. Tocopherols were identified by comparing retention times and peak area values with the standards. The total tocopherol content was calculated as the sum of each tocopherol and expressed as $\mathrm{mg} / \mathrm{kg}$ for samples.

Statistical analysis The mean value and standard deviation were calculated from the data obtained from three samples. One way ANOVA was used to determine the significance of differences at $P<0.05$. All statistical tests were performed using SPSS 13.0 for Windows (SPSS Inc., Chicago, IL. USA).

\section{Results and Discussion}

HPLC chromatograms of the standard mixture of tocopherols, shrimp, European perch and gilthead bream are given in Figure 1. Separation of four tocopherols $(\alpha, \beta, \gamma$ and $\delta)$ was completely achieved using continuous isocratic elution with acetonitrile and methanol (1:1, by vol). The regression coefficient of 8 replicate standard injections was 0.9999 in the concentrations of $0.01 \mathrm{mg} / \mathrm{mL}, 0.1 \mathrm{mg} / \mathrm{mL}, 1 \mathrm{mg} / \mathrm{mL}$ and $10 \mathrm{mg} / \mathrm{mL}$ for each tocopherol, respectively. Huo et al. (1997) developed a method to determine tocopherol in microalgae, and they also achieved similar linearity for $\alpha$ - and $\gamma$-tocopherols using reversed-phase HPLC with fluorescence detection. The total recoveries for each tocopherol were 99.7, 99.9, 99.8 and $99.7 \%$ for $\alpha, \beta, \gamma$ and $\delta$, respectively. Huo et al. (1999) achieved recoveries between 97.7 and $100.8 \%$ to determine $\alpha$-tocopheryl acetate and tocopherol in aquatic organisms and fish feed for concentration of 2.1 and 20.5 $\mu \mathrm{g} / \mathrm{mL}$, respectively. In the present study, relative standard deviations (RSD) of $\alpha-, \beta$-, $\gamma$ - and $\delta$-tocopherols in all levels were $12.4,8.3,10.2$ and $7.6 \%$, respectively.

$\alpha$-Tocopherol is generally the only tocopherol present in oils from marine fish, and its concentration is low (Kulas et al., 2002). However, other tocopherol forms besides $\alpha$-tocopherol have recently been considered to be of biological importance (Wagner et al., 2004; Kornsteiner et al., 2006). In the present study, $\beta-, \gamma$ - and $\delta$-tocopherols as well as $\alpha$-tocopherol in samples analyzed were determined (Table 1). Major tocopherol was alpha-tocopherol in marine and fresh water fish species tested, although the ratio of gammatocopherol was somewhat higher in Atlantic salmon. The extraction and analytical methods developed can be used to provide specific and precise results. Significant differences were observed in the content of tocopherol among the some fish species $(P<0.05)$. Among the analyzed fish species, shrimp, Atlantic salmon, and European perch had the highest content of tocopherol, with values of $81.3,72.9$ and $40.8 \mathrm{mg} /$ $\mathrm{kg}$, respectively. The lowest tocopherol content was observed 

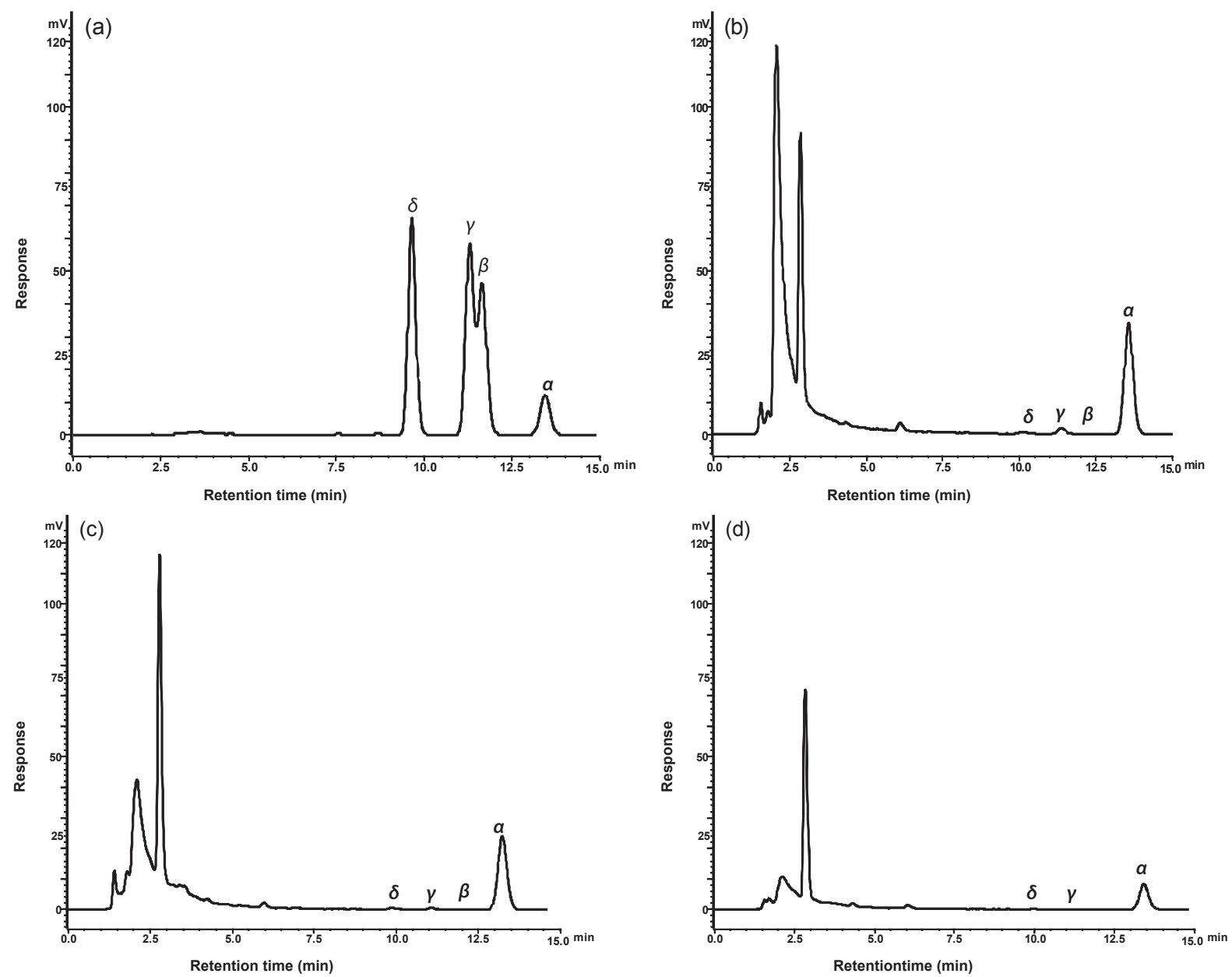

Fig. 1. HPLC chromatogram for a standard mixture of $\alpha$-, $\beta$-, $\gamma$-, and $\delta$-tocopherols (each $10 \mathrm{mg} / \mathrm{mL}$ ) (a), shrimp (b), European perch (c) and gilthead seabream $(\mathrm{d})$.

Table 1. Tocopherol content of some fish species.

\begin{tabular}{|c|c|c|c|c|c|}
\hline \multirow{2}{*}{ Fish Name } & \multicolumn{5}{|c|}{ Tocopherol content (mg/kg) } \\
\hline & $\alpha$ & $\beta$ & $\gamma$ & $\delta$ & Total \\
\hline Whiting (Merlangius merlangus) & $9.45^{\mathrm{g}} \pm 1.27$ & $0.08^{\mathrm{ab}} \pm 0.04$ & $0.13^{b} \pm 0.04$ & $0.13^{\mathrm{c}} \pm 0.04$ & $9.78^{\mathrm{e}} \pm 0.35$ \\
\hline Red mullet (Mullus barbatus barbatus) & $29.28^{\mathrm{de}} \pm 2.72$ & $0.08^{\mathrm{ab}} \pm 0.04$ & $0.13^{\mathrm{b}} \pm 0.04$ & $0.10^{\mathrm{c}} \pm 0.07$ & $29.59^{\mathrm{c}} \pm 0.72$ \\
\hline Atlantic salmon (Salmo salar) & $54.40^{\mathrm{b}} \pm 1.2$ & Not detected & $17.98^{\mathrm{a}} \pm 1.10$ & $0.50^{\mathrm{a}} \pm 0.12$ & $72.88^{a} \pm 0.03$ \\
\hline Atlantic horse mackerel (Trachurus trachurus) & $21.08^{\mathrm{ef}} \pm 2.09$ & $0.08^{\mathrm{ab}} \pm 0.00$ & $0.05^{\mathrm{e}} \pm 0.00$ & $0.05^{\mathrm{c}} \pm 0.00$ & $21.26^{\mathrm{d}} \pm 0.52$ \\
\hline Common sole (Solea solea) & $17.38^{\mathrm{f}} \pm 1.87$ & $0.05^{\mathrm{bc}} \pm 0.00$ & $0.05^{\mathrm{e}} \pm 0.00$ & $0.10^{\mathrm{c}} \pm 0.07$ & $17.58^{\mathrm{d}} \pm 0.49$ \\
\hline Common seabream (Pagrus pagrus) & $28.63^{\mathrm{de}} \pm 3.29$ & $0.03^{\mathrm{cd}} \pm 0.02$ & $0.05^{\mathrm{e}} \pm 0.00$ & $0.43^{\mathrm{a}} \pm 0.04$ & $29.14^{\mathrm{c}} \pm 0.84$ \\
\hline Gilthead seabream (Sparus aurata) & $26.90^{\mathrm{def}} \pm 3.61$ & $0.10^{\mathrm{a}} \pm 0.07$ & $0.08^{\mathrm{e}} \pm 0.04$ & $0.13^{\mathrm{c}} \pm 0.04$ & $27.21^{c} \pm 0.94$ \\
\hline European perch (Perca fluviatilis) & $50.85^{\mathrm{b}} \pm 0.71$ & $0.10^{\mathrm{a}} \pm 0.00$ & $0.35^{\mathrm{d}} \pm 0.00$ & $0.20^{\mathrm{bc}} \pm 0.00$ & $51.50^{\mathrm{b}} \pm 0.18$ \\
\hline European anchovy (Engraulis encrasicolus) & $40.53^{\mathrm{bc}} \pm 2.93$ & $0.08^{\mathrm{ab}} \pm 0.04$ & $0.10^{\mathrm{b}} \pm 0.00$ & $0.13^{\mathrm{c}} \pm 0.04$ & $40.84^{\mathrm{b}} \pm 0.75$ \\
\hline European eel (Anguilla anguilla) & $36.83^{\mathrm{c}} \pm 0.6$ & $0.05^{\mathrm{bc}} \pm 0.00$ & $0.83^{\mathrm{c}} \pm 0.00$ & $0.08^{\mathrm{c}} \pm 0.00$ & $37.79^{\text {bc }} \pm 0.15$ \\
\hline Shrimp (Parapenaus longirostris) & $79.25^{\mathrm{a}} \pm 4.31$ & $0.08^{\mathrm{ab}} \pm 0.00$ & $1.55^{\mathrm{b}} \pm 0.00$ & $0.40^{\mathrm{a}} \pm 0.00$ & $81.28^{\mathrm{a}} \pm 1.08$ \\
\hline
\end{tabular}

Each value is expressed as mean \pm standard deviation $(n=3)$. Different superscripts $(\mathrm{a}-\mathrm{g})$ in a column indicate significant differences among fish species $(P<0.05)$.

for whiting with a value of $9.8 \mathrm{mg} / \mathrm{kg}$. Syvaoja et al. (1985) reported that cod contained only $\alpha$-tocopherol with the value of $10.5 \mathrm{mg} / \mathrm{kg}$ while salmon contained $\alpha-(20.2 \mathrm{mg} / \mathrm{kg})$ and $\gamma$-tocopherol $(0.2 \mathrm{mg} / \mathrm{kg})$. Ackman and Cormier (1967) reported an $\alpha$-tocopherol content of $15 \mathrm{mg} / \mathrm{kg}$ for mackerel.
$\alpha$-Tocopherol in bream and perch was 29 and $15 \mathrm{mg} / \mathrm{kg}$, respectively (Syvaoja et al., 1985). Nogala-Kalucka (2003) reported that the tocopherol content of herring, mackerel and salmon was $15 \mathrm{mg} / \mathrm{kg}, 16 \mathrm{mg} / \mathrm{kg}$ and $9 \mathrm{mg} / \mathrm{kg}$, respectively. Ruff et al. (2002) found a lower $\alpha$-tocopherol content 
for turbot than Atlantic halibut $(2.8 \mathrm{mg} / \mathrm{kg}$ vs $5.7 \mathrm{mg} / \mathrm{kg})$. Bhadra et al. (2004) found only $\alpha$-tocopherol in sardine, sea bream, horse mackerel and flat fish species and reported that the highest $\alpha$-tocopherol content was observed for sardine $(16 \mathrm{mg} / \mathrm{kg})$. Higher tocopherol results found in this study, as reported by Kramer et al. (1997) may reflect the success of used method to recover more of the tocopherols from tissues.

As a result of this research, a rapid, simple and useful method for tocopherol analysis has been developed. Therefore, a large number of fish samples could be analysed in a short time. It was also demonstrated that the method is specific, precise, accurate and practical enough for the determination of tocopherol in seafood.

\section{References}

Ackman, R.G. and Cormier, M.G. (1967). $\alpha$-Tocopherol in some Atlantic fish and shellfish with particular reference to live-holding without food. J. Fish.Res. Board Canada, 24, 357-373.

A.O.A.C., (Official Methods of Analysis International) (2000). "Infant Formulas, Baby Foods, and Enteral Products." AOAC Official Method 992.03, 17th edn. chap. 50.

Bhadra, A., Yamaguchi. T., Takamur, A.H. and Matoba, T. (2004). Radical-Scavenging Activity: Role of Antioxidative Vitamins in Some Fish Species. Food Sci. Technol. Res., 10, 264-267.

CEN (European Committee for Standardisation) (2000). Foodstuffs Determination of Vitamin E by HPLC. CEN/TC 275/WG 9.Determination of alpha, beta, delta and gamma tocopherols.

Eitenmiller, R. and Lee, J. (2004). "Analysis of Tocopherols and Tocotrienols in Foods.” Marcel Dekker Inc.,USA.

Garrow, J.S., James, W.P. and Ralph, A. (2000). "Human nutrition and dietetics." Edinburgh, Churchill Livingstone.

Huo, J.Z., Nelis, H.J., Lavens, P., Sorgeloos, P. and Leenheer, A.R.D. (1997). Determination of E vitamers in microalgae using highperformance liquid chromatography with fluorescence detection. J. Chromatogr. A, 782, 63-68.

Huo, J.Z., Nelis, H.J., Lavens, P., Sorgeloos, P. and De Leenheer, A.P. (1999). Simultaneous determination of $\alpha$-tocopheryl acetate and tocopherols in aquatic organisms and fish feed. J. Chromatogr. $B, \mathbf{7 2 4}, 249-255$.

Kornsteiner, M., Wagner, K.H. and Elmadfa, I. (2006). Tocopherols and total phenolics in 10 different nut types. Food Chem., 98, 381-387.

Kramer, J.K.G., Blais, L., Fouchard, R.C., Melnyk, R.A. and Kallury, K.M.R. (1997). A rapid method for the determination of vitamin e forms in tissues and diet by high- performance liquid chromatography using a normal-phase diol column. Lipids, 32, 323-330.

Kulas, E., Olsen, E. and Ackman, R.G. (2002). Effect of $\alpha$-, $\gamma$-, and $\delta$-tocopherol on the distribution of volatile secondary oxidation products in fish oil. Eur. J. Lipid Sci. Technol., 104, 520-529.
Li, D., Saldeen, T. and Mehta, J.L. (1999). $\gamma$-Tocopherol decreases ox-ldl-mediated activation of nuclear factor- $\mathrm{kb}$ and apoptosis in human coronary artery endothelial cells. Biochem. Bioph. Res. Co., 259, 157-161.

L.M.B.G., (Lebensmittel- und Bedarfsgegenstaendegesetz) (1996). Untersuchung von lebensmitteln - bestimmung von tocopherolen und tocotrienolen in dieta"tischen lebensmitteln collection of official methods under article 35 of the German Federal Foods Act.

Ng, W.K., Wang, Y., Ketchimenina, P. and Yuen, K.H. (2004). Replacement of dietary fish oil with palm fatty acid distillate elevates tocopherol and tocotrienol concentrations and increases oxidative stability in the muscle of African catfish, Clarias gariepinus. Aquaculture, 233, 423-437.

Nogala-Kalucka, M. (2003). Fat-Soluble vitamins. In "Chemical and Functional Properties of Food Lipid,” ed. by E.Z. Sikorski and A. Kolakowska. CRC Press,USA.

Nirungsan, K., and Thongnopnua, P. (2006). Simple and rapid high performance liquid chromatographic method for endogenous $\alpha$-tocopherol determination in human plasma. Biomed. Chromatogr., 20, 774-781.

Porter, N.A., Caldwell, S.E. and Mills, K.A. (1995). Mechanisms of free radical oxidation of unsaturated lipids. Lipids, 30, 277-290.

Ribarova, F., Zanev, R., Shishkov, S. and Rizov, N. (2003). $\alpha$-Tocopherol, fatty acids and their correlations in Bulgarian foodstuffs. J. Food Compos. Anal., 16, 659-667.

Ruff, N., Fitzgerald, R.D., Cross, T. F. and Kerry, J.P. (2002). Comparative composition and shelf-life of fillets of wild and cultured turbot (Scophthalmus maximus) and Atlantic halibut (Hippoglossus hippoglossus). Aquaculture Int., 10, 241-256.

Schmit, J.A., Henry, R.A., Williams, R.C. and Diekman, J.F. (1971). Applications of high speed reversed phase chromatography. $J$. Chromatogr. Sci., 9, 645-651.

Schoene, N.W. (2001). Vitamin E and fatty acids: Effectors of platelet responsiveness. Nutrition, 17, 793-796.

Sinclair, A.J., Murphy, K.L. and Li, D. (2000). Lipides marins: Revue nouvelles approches et composition lipidiques de lyprinolt. Allerg. Immunol., 7, 261-271.

Slover, H. (1970). Tocopherols in Foods and Fats. Lipids, 6, 291296.

Syvaoja, E.L., Piironen, V., Varo, P., Kerojoki, O., Koivistoinen, P. and Salminen, K. (1985). Tocopherols and tocotrienols in Finnish foods: fish and fish products. J. Am. Oil Chem. Soc., 62, 1245.

Wagner, K.H., Kamal-Eldin, A. and Elmadfa, I. (2004). $\gamma$-Tocopherol - an underestimated vitamin. Ann. Nutr. Metab., 48, 169-188.

Weisburger, J.H. (1997). Dietary fat and risk of chronic disease. Mechanistic insights from experimental studies. J. Am. Diet. Assoc., 97, 516-523.

Williams, R.C., Schmit, J.A. and Henry, R.A. (1972). Quantitative analysis of fat-soluble vitamins by high-speed liquid chromatography. J. Chromatogr. Sci., 10, 4984-501. 